\title{
Synthesis of Azalurenone Alkaloids by Pd- mediated Intramolecular Oxidative Cyclisation Protocol
}

\author{
Jayanta K. Ray
}

Department of Chemistry, Indian Institute of Technology, Kharagpur -721302 India

jkray@chem.iitkgp.ac.in

\section{Introduction}

The formation of $\mathrm{C}-\mathrm{C}$ bonds remains the major synthetic challenge in organic chemistry. The use of transition metals in forming the $\mathrm{C}-\mathrm{C}$ bonds was probably the most studied area of research in organic synthesis in the last half of the century. ${ }^{1}$ Among the transition metals palladium was the most relied one to be used in organic synthesis. This reliance made it to award the Nobel Prize in 2010 in chemistry on transition metal catalysed cross-coupling reactions. ${ }^{2}$ The palladium sometimes prove to be superior to the others owing to 1) compatible with different functional groups 2 ) it can functionalize all three types $\mathrm{sp}^{3}, \mathrm{sp}^{2}$ and sp carbon atoms 3) most of the palladium catalyst can tolerate air and moisture, and produces desired compounds in reasonably milder reaction conditions. ${ }^{3}$ Furthermore, palladium shows low toxicity and easy to separate from the reaction mixture after the reaction is complete.

Fluorenone (2.1) is a cyclopentenone derivatives containing a five-member ketone fused with two benzene rings. When one of the fused benzene ring is substituted by pyridine ring compound referred to as azafluorenone (2.2) (Fig. 2.1).

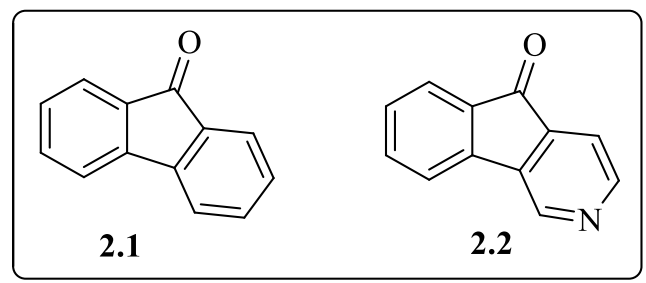

Fig. 2.1 Fluorenone and azafluorenone

The Azafluorenones constitute a growing class of alkaloids. The representative alkaloids of this kind having potential bioactivity include the compounds 2.3-2.5 as shown in Fig. 2.2. ${ }^{4}$ Onychine (2.3) showed activity against C. albicans B311 and also exhibited antimicrobial activity against $S$. aureus NCTC8530, B subtitles IFO 3007, Escherichia coli IFO 3545 and Saccharomyces cerevisiae IFO 0203. ${ }^{5,6}$ Polyfothine (2.4) shows DNA-damaging activity. ${ }^{7}$ 
Isoursuline (2.5) showed anti-malarial activity against Plasmodium falciparum at micromolar concentrations. ${ }^{8}$ Considering the importance of azafluorenones, a general and convenient synthetic methodology still is ongoing research. Several such compounds and their derivatives are important for biomedical applications ${ }^{9-31}$.

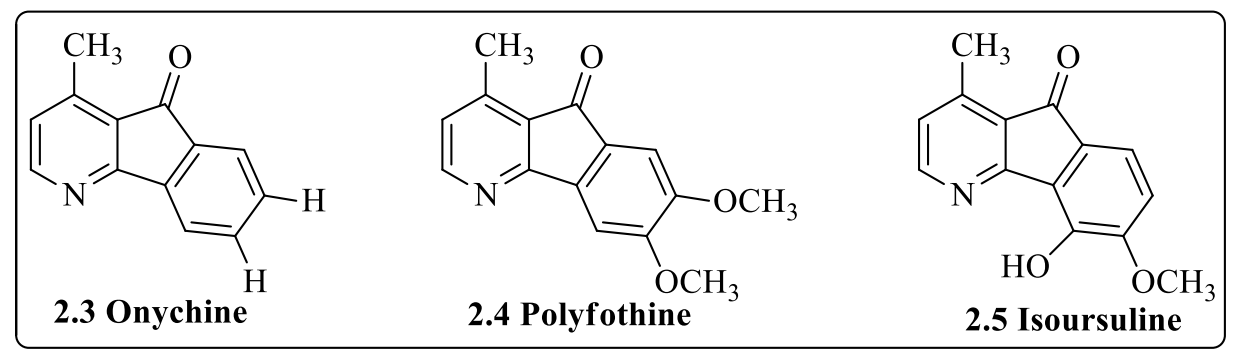

Fig. 2.2: Some bioactive azafluorenone alkaloids

Nitrogen containing heterocyclic compounds is prevalent in a wide range of naturally occurring bioactive molecules and clinical medicines. ${ }^{32}$ The azafluorenone represent a major portion of these types. Construction of azafluorenone ring system is an emerging field of research for the last few decades. Several attempted syntheses have been reported in literature. Different group of chemists have accomplished the synthesis of azafluorenones via both the catalytic and non-catalytic ways. But, still development of new synthetic strategies is needed to meet the structural diversity and synthetic challenges. Among the reported procedures, Sreekumar et al. ${ }^{33}$ have synthesized substituted azafluorenone 2.7 by zeolite catalyzed cyclization of appropriately substituted arylpyridines $\mathbf{2 . 6}$ (Scheme 2.1).

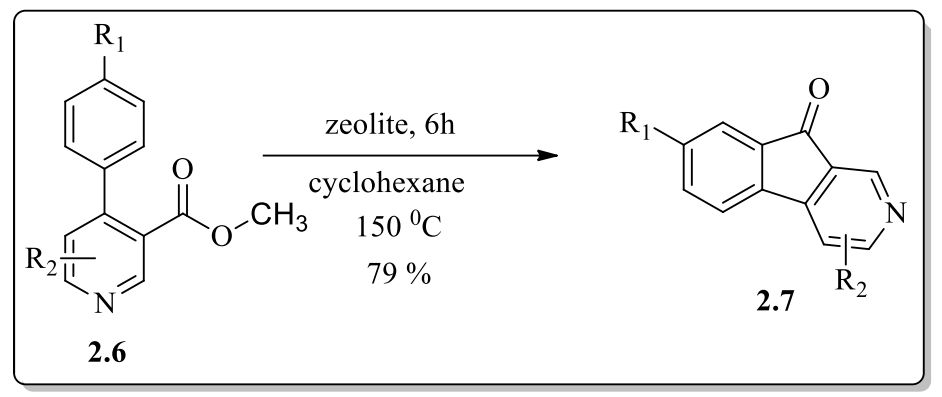

Scheme 2.1: zeolite catalysed synthesis of azafluorenone

In alternative approach a LDA mediated ring closing of 2-(2 and 4-pyridyl)-benzoic acids 2.8 has been reported by Mongin et al. ${ }^{34}$ to synthesize azafluorenone 2.9 (Scheme 2.2). At room temperature LDA abstracts the remote hydrogen in the pyridine ring, and this lithiated intermediate undergos an intra-molecular cyclization to afford the azafluorenone in $52 \%$ yields. 


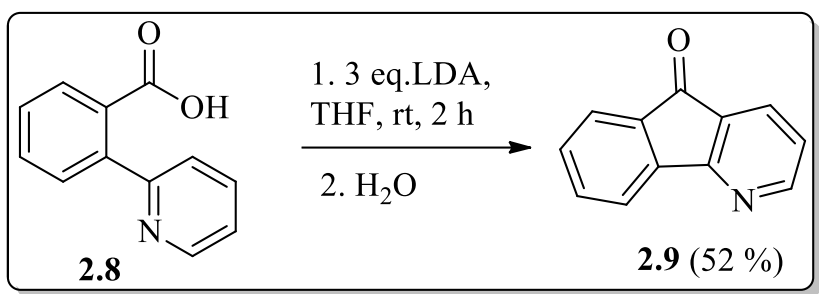

Scheme 2.2: LDA mediated synthesis.

Kraus et al. ${ }^{4}$ devised a three step protocol for the formation of azafluorenone $\mathbf{2 . 1 4}$ via nucleophilic attack of 3-lithio-4-methylpyridine $\mathbf{2 . 1 0}$ on suitably substituted 2bromobenzaldehyde $\mathbf{2 . 1 1}$ followed by successive steps of $\mathrm{MnO}_{2}$ oxidation of resulting alcohols 2.12 and the Heck cyclization of keto compounds 2.13 to afford 2.14 in $53 \%$ yield (Scheme 2.3).

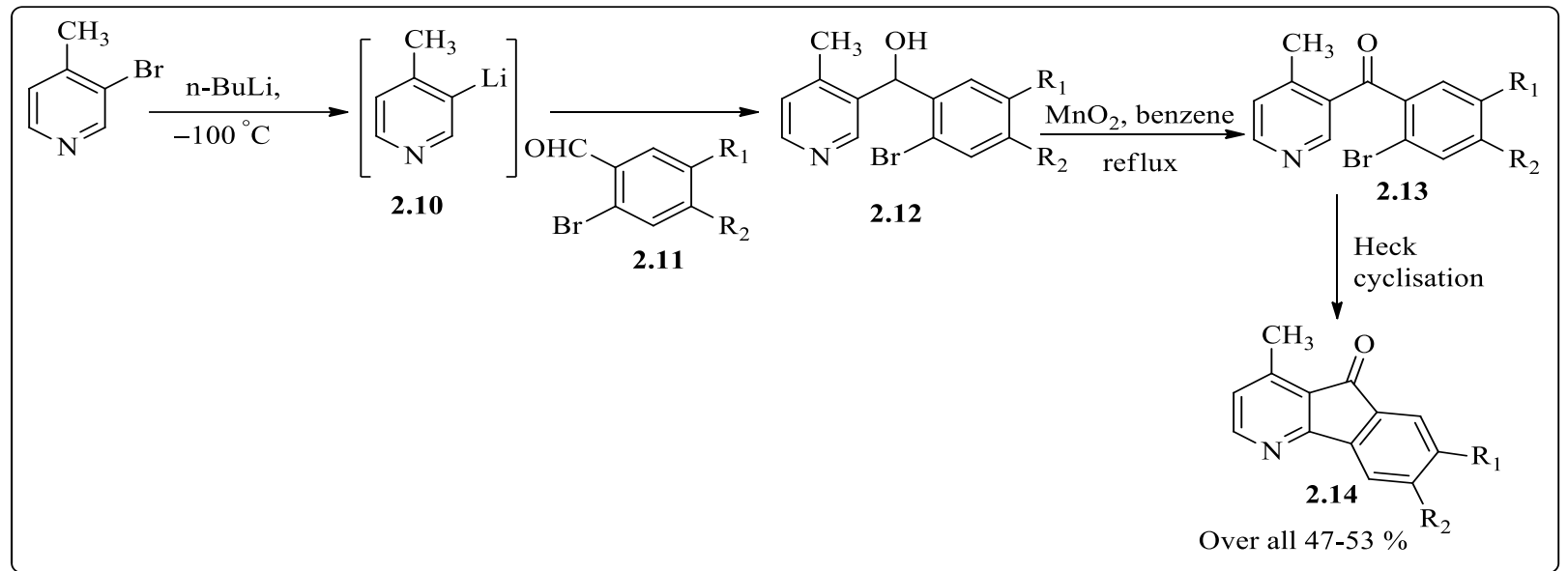

Scheme 2.3: Three step synthesis azafluorenone

A one pot synthesis of azabiaryls has been achieved by Snieckus et al. via Pd-catalysed Suzuki-Miyaura cross-coupling of $\mathbf{2 . 1 5}$ and arylhalide to form the biaryl intermediate 2.16. The resulting biaryl 2.16 were condensed to azafluorenone 2.17 via LDA mediated cyclization in $81 \%$ of yields (Scheme 2.4$){ }^{35}$

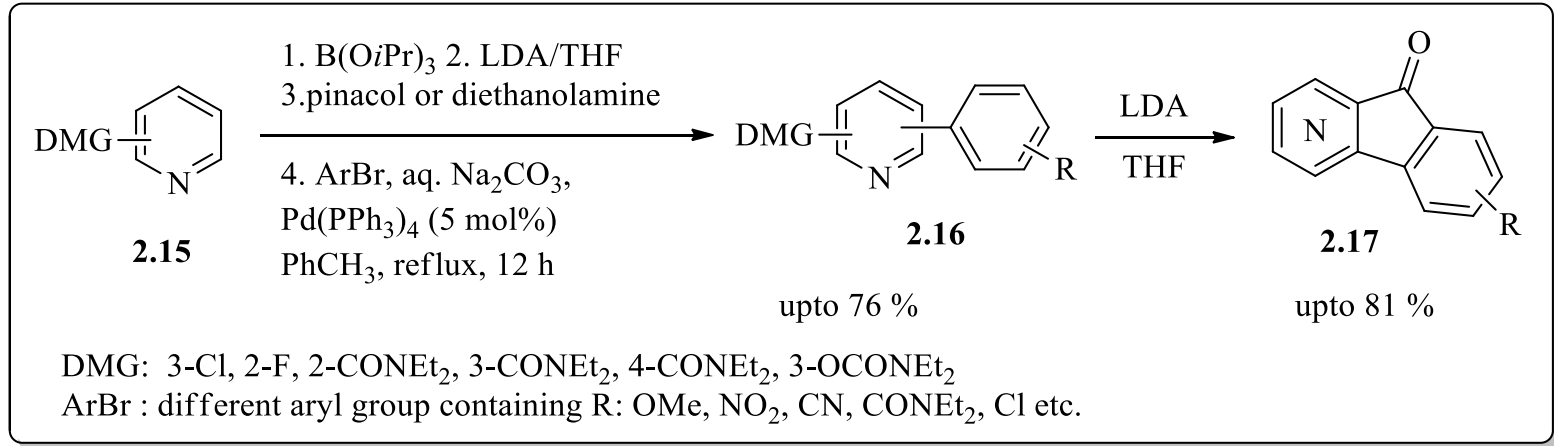

Scheme 2.4: One pot synthesis of azabiaryls 
A three-component reaction strategy has been adopted by Constantieux and co-workers to synthesize azafluoreone and substituted pyridine derivatives (Scheme 2.5). Metal free Michael-addition mediated three component reaction between suitable acceptor $\mathbf{2 . 1 8}$, donor 2.19 and ammonium acetate results the formation of 3-methylazafluorenone $\mathbf{2 . 2 0}$ in good yields. ${ }^{36}$

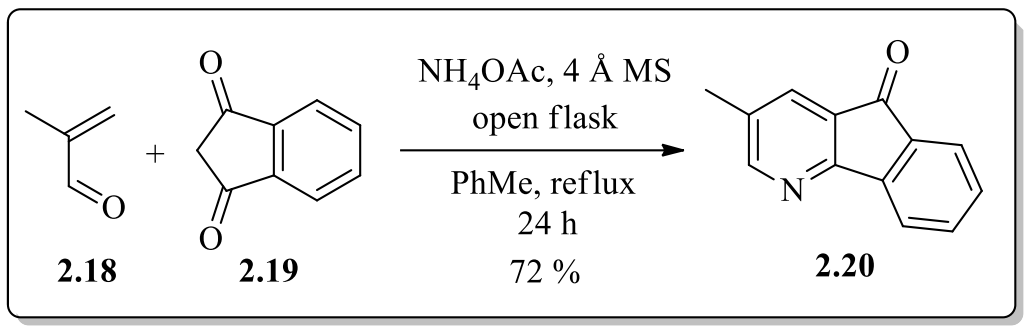

Scheme 2.5: Three component reaction for the synthesis of azafluorenone

In another report Mongin groups described a Pd-catalyzed intramolecular arylation of diaryl ketone to synthesize azafluorenone. Different diaryl ketone $\mathbf{2 . 2 1}$ containing chlorine at the 2position undergoes a $\mathrm{Pd}$-catalyzed $\mathrm{CH}$ - activation type intramolecular arylation to afford the azafluorenone $\mathbf{2 . 2 2}$ in good to excellent yields (Scheme 2.6). ${ }^{13}$

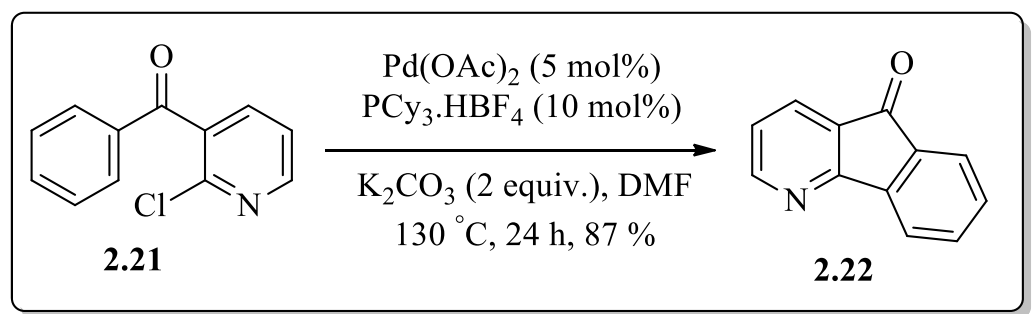

Scheme 2.6: Pd-catalysed synthesis of azafluorenone

In continuation of our search for the Pd-catalyzed new reactions methodologies, we mainly focused on development of newer synthetic routes for the construction of carbocycles and heterocycles involving Heck type coupling reactions. Recently in our lab, cyclopentenone has been efficiently synthesized via Pd-catalysed intramolecular 5-exo-trig oxidative Heck cyclization. ${ }^{26,}{ }^{37-59}$ In the extension, we aimed to explore the intramolecular oxidative Heck cyclization in synthesizing azafluorenone. Consequently, we have developed a short and efficient method for formation of azafluorenone via intramolecular oxidative Heck cyclization. We envisioned that intramolecular oxidative Heck cyclisation of alcohol $\mathbf{2 . 2 3}$ can be used for the synthesis of azafluorenone $\mathbf{2 . 2 2}$ in two step process (Scheme 2.4). Alcohol 
2.23 can be obtained from reaction of 2-bromopyidine-3-carboxaldehyde $\mathbf{2 . 2 5}$ and corresponding Grignard reagent $\mathbf{2 . 2 4}$ of the iodobenzene.

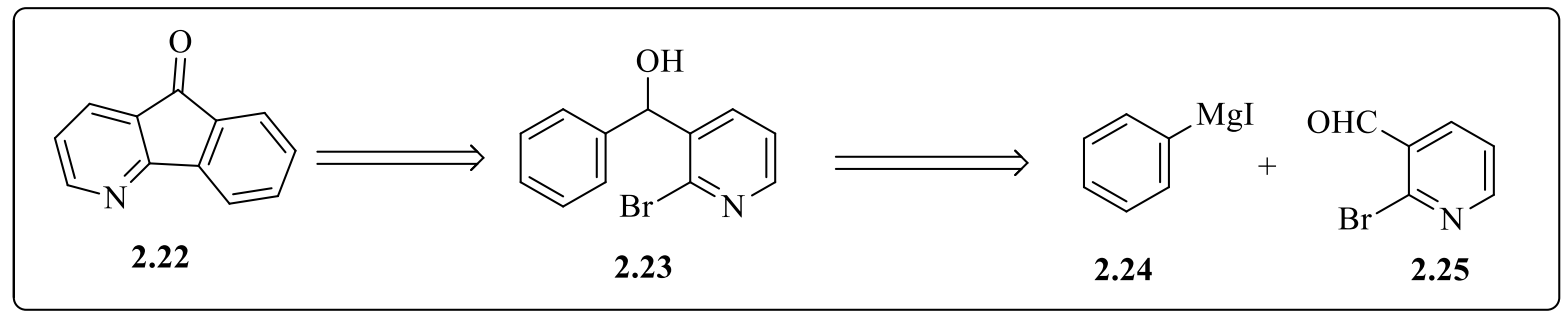

Scheme 2.4: Retrosynthetic analysis

\section{Results and discussion}

In this paper we present the synthesis of different substituted azafluorenone via oxidative intra-molecular Heck cyclization protocol. The Heck precursor alcohols 2.23a-h were synthesised via reaction of the Grignard reagents $\mathbf{2 . 2 4 a - h}$ of corresponding iodides upon 2bromopyridine-3-carboxaldehyde $\mathbf{2 . 2 5}$. The Grignard reagents were easily prepared from fresh magnesium turnings activated by pinch of iodine and their corresponding halides (iodide or bromide) in refluxing dry ether medium. Then these freshly prepared Grignard reagents were added drop wise into an ice-cold ethereal solution of 2-bromoprydine-3carboxaldehyde 2.25, which gave our desired Heck precursor alcohols 2.23a-h in quantitative yields (Scheme 2.5). The results are shown in the Table 2.1. And finally these alcohols 2.23ah when subjected to the Heck reaction conditions afforded different substituted azafluorenones (Scheme 2.6).

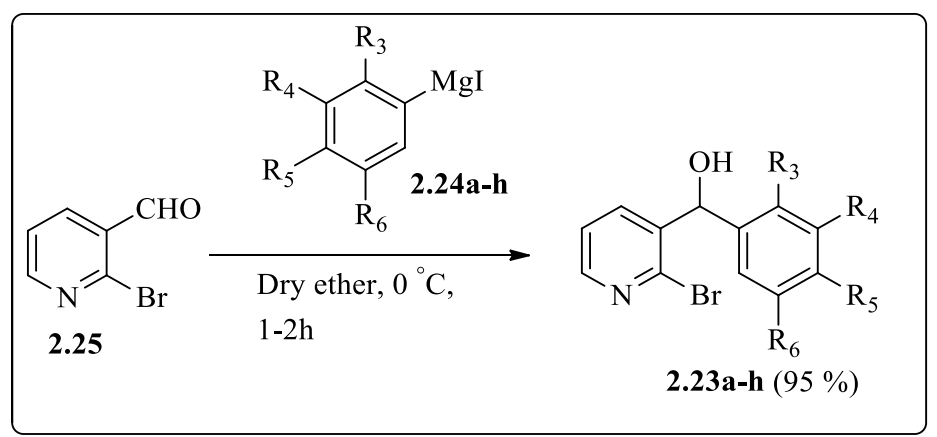

Scheme 2.5: Synthesis of alcohol precursors

Table 2.1: Synthesis of the cyclization precursor alcohol ${ }^{\mathrm{a}}$ 


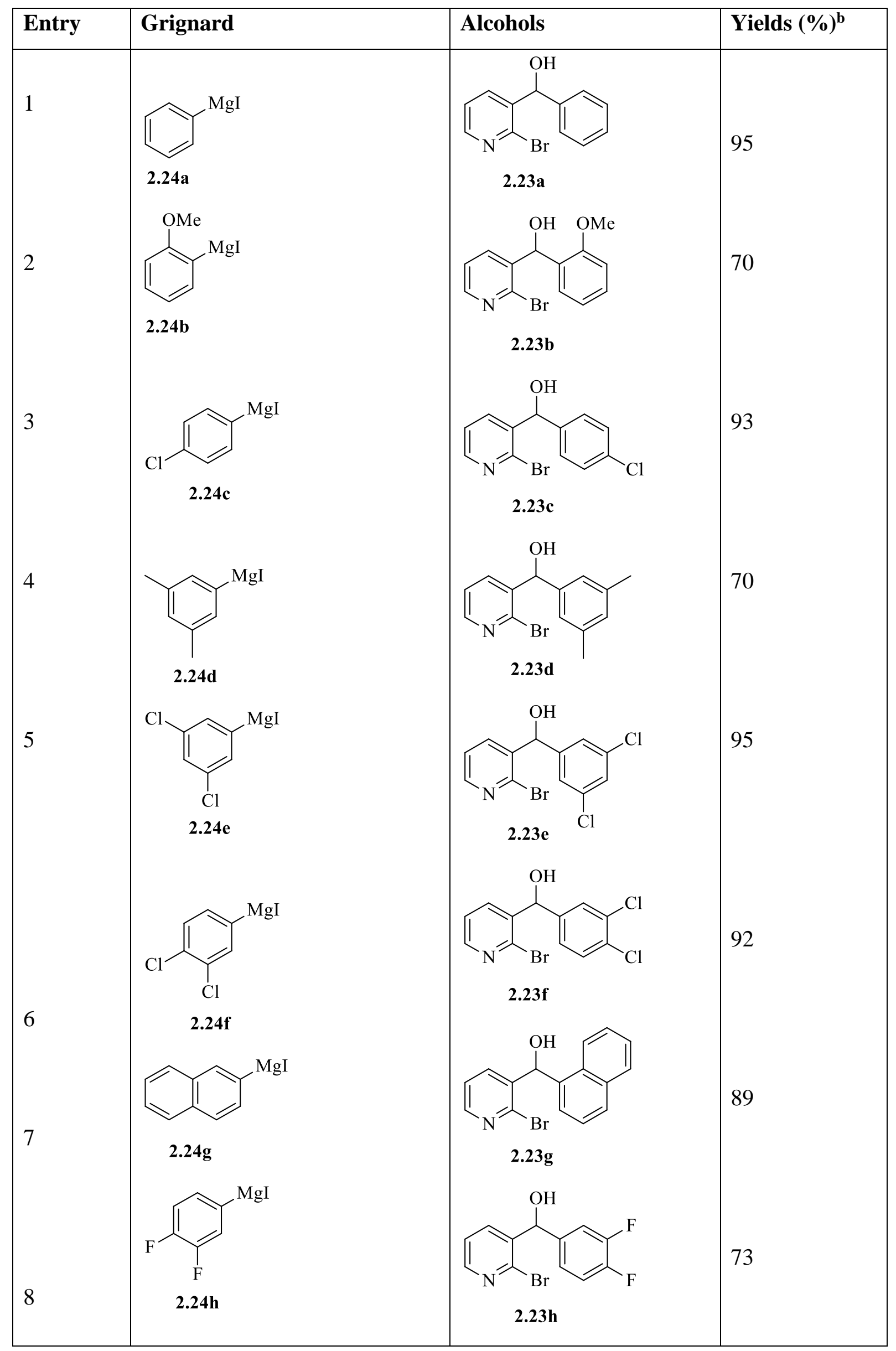


a) Fresh Mg turnings (3 equiv. w. r. to iodocompounds), pinch of iodine, flame heating for activation $\mathrm{Mg}, 2-3 \mathrm{~mL}$ of $\operatorname{dry~}^{\mathrm{E}} \mathrm{t}_{2} \mathrm{O}$, iodo compound (1.5 equiv. w. r. to aldehyde substrate), room temperature, $1 \mathrm{~h}$.

b) Isolated yields after purification.

Initially we started our journey for the oxidative cyclization with the alcohol 2.23a. When representative alcohol 2.23a was reacted with the catalytic system of $\mathrm{Pd}(\mathrm{OAc})_{2}, \mathrm{Cs}_{2} \mathrm{CO}_{3}$ and $\mathrm{PPh}_{3}$ it gave 2.26a in $50 \%$ yields at $80{ }^{\circ} \mathrm{C}$ temperature. Changing the base $\mathrm{Cs}_{2} \mathrm{CO}_{3}$ to $\mathrm{Na}_{2} \mathrm{CO}_{3}$ increase the product formation upto $83 \%$. A further increment of formation of azafluorenone to $95 \%$ was obtained while using $\mathrm{NaOAc}$ and, with increasing the reaction temperature from $80{ }^{\circ} \mathrm{C}$ to $100{ }^{\circ} \mathrm{C}$. During the search of finding a standard cyclization reaction conditions it was observed that absence of the ligand did not hampered the product formation. Among the sources of palladium (0) catalysts, $\mathrm{Pd}\left(\mathrm{PPh}_{3}\right)_{4}$ and $\mathrm{Pd}_{2}(\mathrm{dba})_{3}$ gave the formation of only $50 \%$ and $52 \%$ of $\mathbf{2 . 2 6 a}$ respectively (entry 7,9; Table 2.2). The formation of $40 \%$ to $86 \%$ of $\mathbf{2 . 2 6 a}$ was obtained at the elevated temperature of $100{ }^{\circ} \mathrm{C}$ using other palladium(II) source, such as $\mathrm{PdCl}_{2}, \mathrm{Pd}\left(\mathrm{PPh}_{3}\right)_{2} \mathrm{Cl}_{2}$ etc. The $\mathrm{Pd}(\mathrm{OAc})_{2}(5 \mathrm{~mol} \%)$ and $\mathrm{NaOAc}$ (2.5 equiv.) was found to be the most high yielding catalytic system during this study. The azafluorenone 2.26a was obtained in 50 to $87 \%$ yields while using acetonitrile and DMA as solvent. The solvent DMF was proved to be most effective solvent system at $100{ }^{\circ} \mathrm{C}$. During the screening, the optimal reaction conditions was set to be the $\mathrm{Pd}(\mathrm{OAc})_{2}(3 \mathrm{~mol} \%), \mathrm{NaOAc}$ (2.5 equiv.), DMF (3 mL) and, $100{ }^{\circ} \mathrm{C}$ (entry 5 , Table 2$)$.

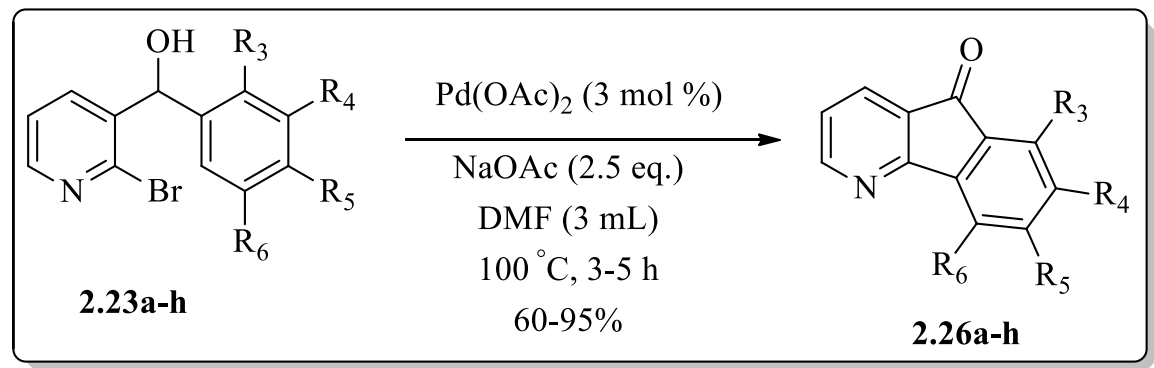

Scheme 2.6: Intramolecular oxidative Heck cyclisation

Table 2.2: Optimisation of intramolecular Heck cyclization ${ }^{b}$ 


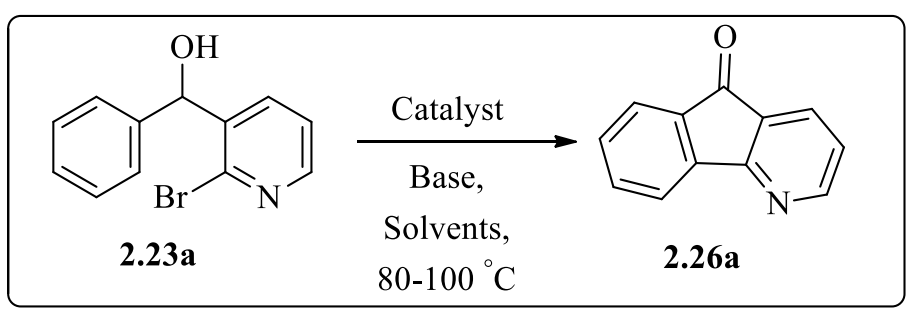

\begin{tabular}{|l|l|l|l|l|l|l|}
\hline Entry & Catalyst & Ligand & Base & Solvent & $\begin{array}{l}\text { Temp } \\
\left({ }^{\circ} \mathrm{C}\right)\end{array}$ & Yields $(\%)^{\mathrm{c}}$ \\
\hline 1 & $\mathrm{Pd}(\mathrm{OAc})_{2}$ & $\mathrm{PPh}_{3}$ & $\mathrm{Cs}_{2} \mathrm{CO}_{3}$ & $\mathrm{DMF}$ & 80 & 50 \\
\hline 2 & $\mathrm{Pd}(\mathrm{OAc})_{2}$ & $\mathrm{PPh}_{3}$ & $\mathrm{~K}_{2} \mathrm{CO}_{3}$ & $\mathrm{DMF}$ & 80 & 70 \\
\hline 3 & $\mathrm{Pd}(\mathrm{OAc})_{2}$ & $\mathrm{PPh}_{3}$ & $\mathrm{Na}_{2} \mathrm{CO}_{3}$ & $\mathrm{DMF}$ & 80 & 83 \\
\hline 4 & $\mathrm{Pd}(\mathrm{OAc})_{2}$ & $\mathrm{PPh}_{3}$ & $\mathrm{NaOAc}$ & $\mathrm{DMF}$ & 100 & 90 \\
\hline 5 & $\mathrm{Pd}(\mathrm{OAc})_{2}$ & - & $\mathrm{NaOAc}$ & $\mathrm{DMF}$ & 100 & 95 \\
\hline 6 & $\mathrm{Pd}\left(\mathrm{CH}_{3} \mathrm{CN}\right)_{2} \mathrm{Cl}_{2}$ & - & $\mathrm{NaOAc}$ & $\mathrm{DMF}$ & 100 & 40 \\
\hline 7 & $\mathrm{Pd}\left(\mathrm{dba}_{3}\right.$ & - & $\mathrm{NaOAc}$ & $\mathrm{DMF}$ & 100 & 50 \\
\hline 8 & $\mathrm{PdCl} 2$ & - & $\mathrm{NaOAc}$ & $\mathrm{DMF}$ & 100 & 86 \\
\hline 9 & $\mathrm{Pd}\left(\mathrm{PPh}_{3}\right)_{4}$ & - & $\mathrm{NaOAc}$ & $\mathrm{DMF}$ & 100 & 52 \\
\hline 10 & $\mathrm{Pd}\left(\mathrm{PPh}_{3}\right)_{2} \mathrm{Cl}_{2}$ & - & $\mathrm{NaOAc}$ & $\mathrm{DMF}$ & 100 & 62 \\
\hline 11 & $\mathrm{Pd}\left(\mathrm{OAc}_{2}\right.$ & - & $\mathrm{NaOAc}$ & $\mathrm{CH}{ }_{3} \mathrm{CN}$ & 100 & 80 \\
\hline 12 & $\mathrm{Pd}\left(\mathrm{OAc}_{2}\right.$ & - & $\mathrm{NaOAc}$ & DMA & 100 & 87 \\
\hline 13 & $\mathrm{Pd}\left(\mathrm{OAc}_{2}\right.$ & - & $\mathrm{NaOH}$ & $\mathrm{DMF}$ & 100 & 53 \\
\hline
\end{tabular}

b) $1 \mathrm{mmol}$ of substrate 2.23a-h, $\mathrm{Pd}(\mathrm{OAc})_{2}$ ( $3 \mathrm{~mol} \%$ ), NaOAc (2.5 equiv.), DMF ( $\left.3 \mathrm{~mL}\right), 100$ ${ }^{0} \mathrm{C}, 3 \mathrm{~h}$.

c) Isolated yields after purification.

Then with the set optimal reaction conditions in hand, we have further studied the general scope and applicability of our reaction protocol. Different substituted azafluorenones (2.26ah) with varying substituents ranging from electron withdrawing to electron donating groups were efficiently synthesized. The results are described in the Table 2.3. It was clear from the Table 2.3 that substituents chloro and fluoro retarded the oxidative cyclisation to afford the azafluorenone in 61 to $75 \%$. In contrast, the electron donating groups, like methyl and methoxy, enhances the oxidative addition with comparatively higher yields of products. Interestingly the naphthalene moiety has been well tolerated by this synthetic method. Our 
findings demonstrate that this synthetic strategy is very general and efficient one with both the electron donating and electron withdrawing substituents.

Table 2.3: Synthesis of azafluorenone derivatives ${ }^{\mathrm{d}}$

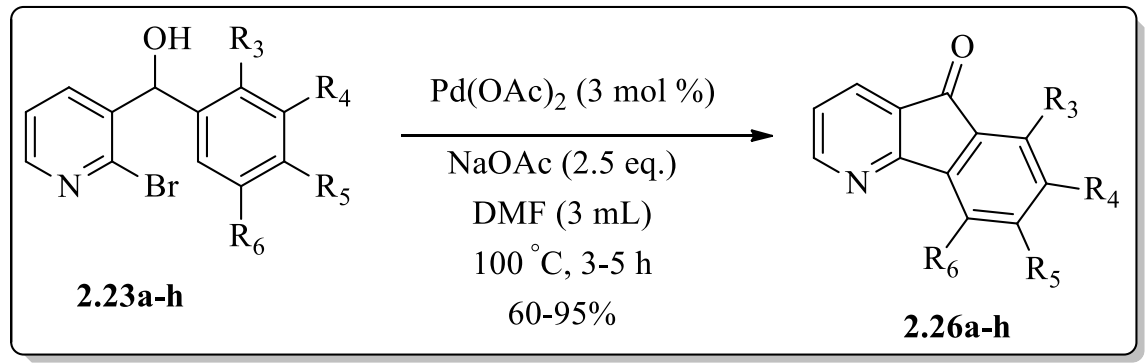

Entry




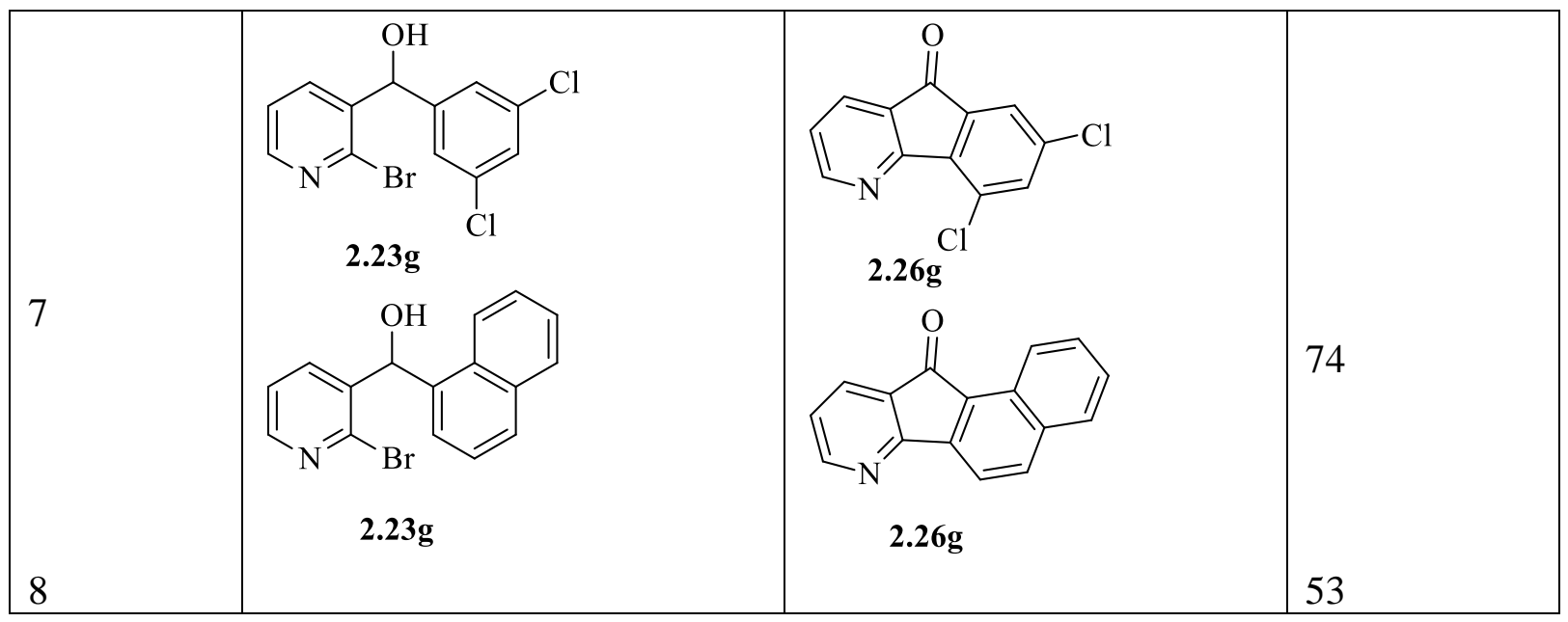

c) $1 \mathrm{mmol}$ of substrate $\mathbf{2 . 2 3 a - h , ~} \mathrm{Pd}(\mathrm{OAc})_{2}$ (3 mol\%), NaOAc (2.5 equiv.), DMF (3 mL), 100 ${ }^{\circ} \mathrm{C}, 3 \mathrm{~h}$.

d) Isolated yields after purification.

While searching the most probable rationale of the reaction, one very interesting observation was that the reaction did not required any added ligand in the catalytic system. Only the catalyst $\mathrm{Pd}(\mathrm{OAc})_{2}$ could complete the whole catalytic cycle to formed the product VI from the starting material I. That is something in the reaction mixture reduced Pd (II) to Pd (0) which was the actual catalyst. We assumed that substrate itself with the nitrogen lone pair in the pyridine moiety can play the ligand's role and reduces Pd (II) to Pd (0) (Fig 2.3) to complete the reaction cycle.

\section{Plausible Reaction Mechanism}

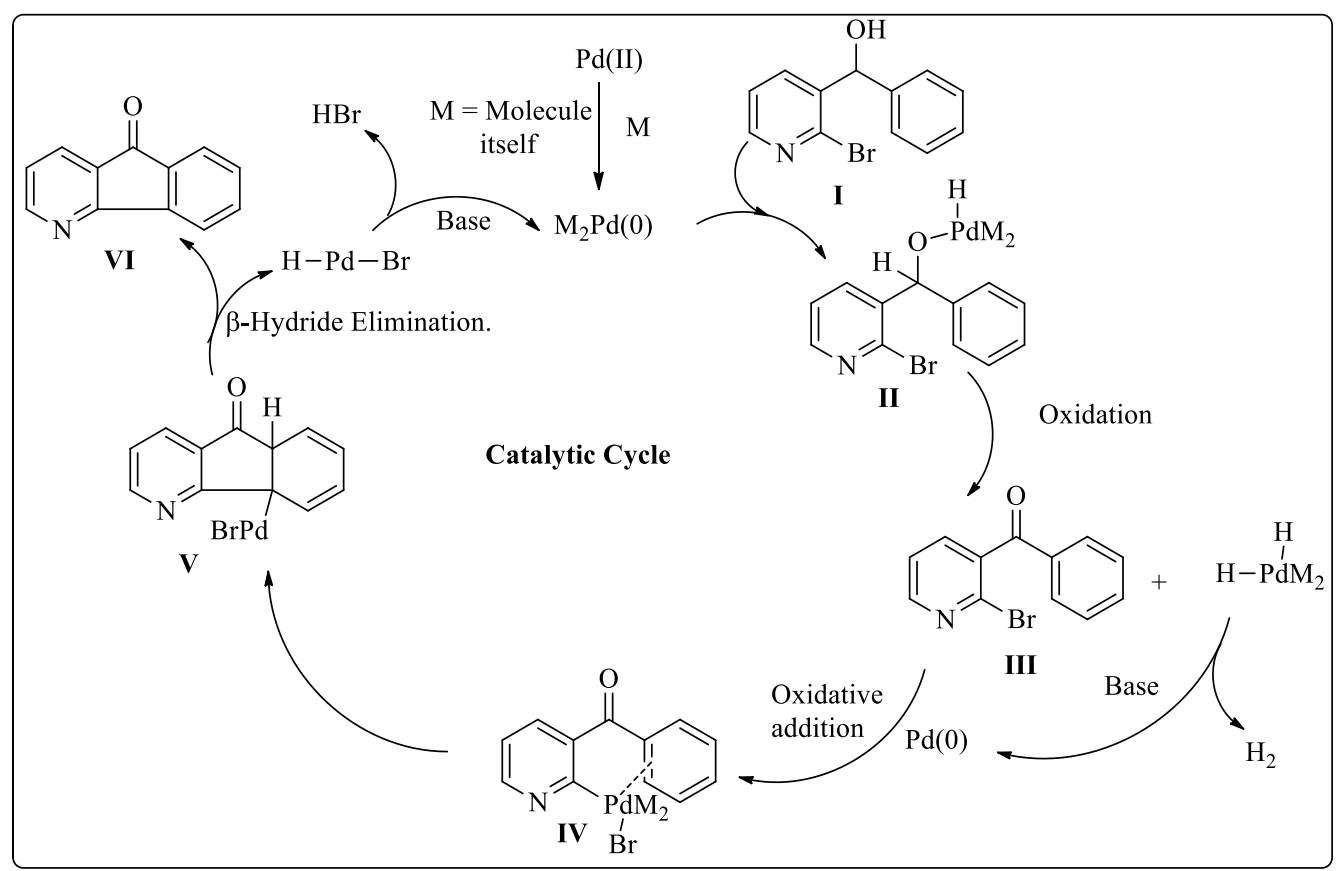


Fig 2.3: Catalytic Cycle of intramolecular Heck cyclisation ${ }^{15}$

\section{Conclusion}

In conclusion, we have developed a two-step strategy for the construction of azafluorenone alkaloids. Our developed method is simple and general one with good range of substrate scope and functional group tolerance. In addition this method needs inexpensive reagents and catalysts and afforded excellent yields of azafluorenone under mild reaction conditions. We believe that our method have the potential to be utilized in total synthesis of azafluorenone based bioactive natural products.

\section{References:}

1. Ojima, I.; Tzamarioudaki, M.; Li, Z.; Donovan, R. J., Transition Metal-Catalyzed Carbocyclizations in Organic Synthesis. Chem Rev 1996, 96 (2), 635-662.

2. Negishi, E.-i., Magical Power of Transition Metals: Past, Present, and Future (Nobel Lecture). Angewandte Chemie International Edition 2011, 50 (30), 6738-6764.

3. Zeni, G.; Larock, R. C., Synthesis of heterocycles via palladium-catalyzed oxidative addition. Chem Rev 2006, 106 (11), 4644-80.

4. Kraus, G. A.; Kempema, A., Synthesis of azafluorenone antimicrobial agents. J Nat Prod 2010, 73 (11), 1967-8.

5. Hufford, C. D.; Liu, S.; Clark, A. M.; Oguntimein, B. O., Anticandidal Activity of Eupolauridine and Onychine, Alkaloids from Cleistopholis patens. Journal of Natural Products 1987, 50 (5), 961-964.

6. Koyama, J.; Morita, I.; Kobayashi, N.; Osakai, T.; Usuki, Y.; Taniguchi, M., Structure-activity relations of azafluorenone and azaanthraquinone as antimicrobial compounds. Bioorganic \& Medicinal Chemistry Letters 2005, 15 (4), 1079-1082.

7. Lago, J. H.; Chaves, M. H.; Ayres, M. C.; Agripino, D. G.; Young, M. C., Evaluation of antifungal and DNA-damaging activities of alkaloids from branches of Porcelia macrocarpa. Planta Med 2007, 73 (3), 292-5.

8. Mueller, D.; Davis, R. A.; Duffy, S.; Avery, V. M.; Camp, D.; Quinn, R. J., Antimalarial activity of azafluorenone alkaloids from the Australian tree Mitrephora diversifolia. J Nat Prod 2009, 72 (8), 1538-40.

9. Ray, P. Calixarenes and Nanoparticles: Synthesis, Properties and Applications. Paris 11, 2013.

10. André, E.; Boutonnet, B.; Charles, P.; Martini, C.; Aguiar-Hualde, J. M.; Latil, S.; Guérineau, V.; Hammad, K.; Ray, P.; Guillot, R.; Huc, V., A New, Simple and Versatile Strategy for the Synthesis of Short Segments of Zigzag-Type Carbon Nanotubes. Chemistry 2016, 22 (9), 3105-14.

11. Ray, P.; Clément, M.; Martini, C.; Abdellah, I.; Beaunier, P.; Rodriguez-Lopez, J.L.; Huc, V.; Remita, H.; Lampre, I., Stabilisation of small mono- and bimetallic gold-silver nanoparticles using calix[8]arene derivatives. New Journal of Chemistry 2018, 42 (17), 14128-14137. 
12. Ray, P.; Confeld, M.; Borowicz, P.; Wang, T.; Mallik, S.; Quadir, M., PEG-b-poly (carbonate)-derived nanocarrier platform with $\mathrm{pH}$-responsive properties for pancreatic cancer combination therapy. Colloids and Surfaces B: Biointerfaces 2019, 174, 126-135.

13. Ray, P.; Alhalhooly, L.; Ghosh, A.; Choi, Y.; Banerjee, S.; Mallik, S.; Banerjee, S.; Quadir, M., Size-Transformable, Multifunctional Nanoparticles from Hyperbranched Polymers for Environment-Specific Therapeutic Delivery. ACS Biomaterials Science \& Engineering 2019, 5 (3), 1354-1365.

14. Ray, P.; Nair, G.; Ghosh, A.; Banerjee, S.; Golovko, M. Y.; Banerjee, S. K.; Reindl, K. M.; Mallik, S.; Quadir, M., Microenvironment-sensing, nanocarrier-mediated delivery of combination chemotherapy for pancreatic cancer. Journal of Cell Communication and Signaling 2019.

15. Ghosh, A.; Sarkar, S.; Ghosh, S.; Ray, P.; Quadir, M.; Banerjee, S. K.; Banerjee, S., Abstract 1234: Zoledronic acid-induced suppression of invasive phenotypes of pancreatic cancer cells is mediated through downregulation of CYR61/CCN1. Cancer Research 2019, 79 (13 Supplement), 1234.

16. Ray, P.; Ferraro, M.; Haag, R.; Quadir, M., Dendritic Polyglycerol-Derived NanoArchitectures as Delivery Platforms of Gemcitabine for Pancreatic Cancer. Macromol Biosci 2019, 19 (7), e1900073.

17. Confeld, M. I.; Mamnoon, B.; Feng, L.; Jensen-Smith, H.; Ray, P.; Froberg, J.; Kim, J.; Hollingsworth, M. A.; Quadir, M.; Choi, Y.; Mallik, S., Targeting the tumor core: hypoxia-responsive nanoparticles for delivery of chemotherapy to pancreatic tumors. Molecular Pharmaceutics 2020.

18. Sarker, N. C.; Ray, P.; Pfau, C.; Kalavacharla, V.; Hossain, K.; Quadir, M., Development of Functional Nanomaterials from Wheat Bran Derived Arabinoxylan for Nucleic Acid Delivery. Journal of Agricultural and Food Chemistry 2020, 68 (15), 43674373.

19. Abdullah, C. S.; Ray, P.; Alam, S.; Kale, N.; Aishwarya, R.; Morshed, M.; Dutta, D.; Hudziak, C.; Banerjee, S. K.; Mallik, S.; Banerjee, S.; Bhuiyan, M. S.; Quadir, M., Chemical Architecture of Block Copolymers Differentially Abrogate Cardiotoxicity and Maintain the Anticancer Efficacy of Doxorubicin. Molecular Pharmaceutics 2020, 17 (12), 4676-4690.

20. Clément, M.; Abdellah, I.; Ray, P.; Martini, C.; Coppel, Y.; Remita, H.; Lampre, I.; Huc, V., Synthesis and NMR study of trimethylphosphine gold(i)-appended calix[8]arenes as precursors of gold nanoparticles. Inorganic Chemistry Frontiers 2020.

21. Das, A.; Haque, I.; Ray, P.; Ghosh, A.; Dutta, D.; Quadir, M.; De, A.; Gunewardena, S.; Chatterjee, I.; Banerjee, S.; Weir, S.; Banerjee, S. K., CCN5 activation by free or encapsulated EGCG is required to render triple-negative breast cancer cell viability and tumor progression. Pharmacol Res Perspect 2021, 9 (2), e00753.

22. Ray, P.; Kale, N.; Quadir, M., New side chain design for $\mathrm{pH}$-responsive block copolymers for drug delivery. Colloids and Surfaces B: Biointerfaces 2021, 200, 111563.

23. Ray, P.; Haideri, N.; Haque, I.; Mohammed, O.; Chakraborty, S.; Banerjee, S.; Quadir, M.; Brinker, A. E.; Banerjee, S. K., The Impact of Nanoparticles on the Immune System: A Gray Zone of Nanomedicine. Journal of Immunological Sciences 2021, 5 (1).

24. Ray, P.; Dutta, D.; Haque, I.; Nair, G.; Mohammed, J.; Parmer, M.; Kale, N.; Orr, M.; Jain, P.; Banerjee, S.; Reindl, K. M.; Mallik, S.; Kambhampati, S.; Banerjee, S. K.; Quadir, M., pH-Sensitive Nanodrug Carriers for Codelivery of ERK Inhibitor and Gemcitabine Enhance the Inhibition of Tumor Growth in Pancreatic Cancer. Molecular Pharmaceutics 2021, 18 (1), 87-100. 
25. Babak, K.; Torabi, M.; Foad, K.; Priyanka, R., Novel $\beta$-Cyclodextrin Functionalized Core-Shell Fe3O4 Magnetic Nanoparticles for the Removal of Toxic Metals from Water. 2021.

26. Brahma, S.; Ray, P.; Ray, J. K., Synthesis of azirines containing aldehyde functionality and their utilization as synthetic tools for five membered oxazoles and isoxazoles (vol 45, pg 311, 2008). JOURNAL OF HETEROCYCLIC CHEMISTRY 2021, 58 (6), 1388-1388.

27. Ray, P., Curing Cancer with Nanotherapy Continues to be an Elusive Goal. Journal of Immunological Sciences 2021, 5 (2).

28. Ray, P., Polymer based drug delivery systems-benchtop to bedside transition. Journal of Drugs Addiction \& Therapeutics. SRC/JDAT-114 2021, 3.

29. Wang, C.-Y.; Ray, P.; Gong, Q.; Zhao, Y.; Li, J.; Lueking, A. D., Influence of gas packing and orientation on FTIR activity for $\mathrm{CO}$ chemisorption to the $\mathrm{Cu}$ paddlewheel. Physical Chemistry Chemical Physics 2015, 17 (40), 26766-26776.

30. Ray, P.; Gray, J. L.; Badding, J. V.; Lueking, A. D., High-Pressure Reactivity of Triptycene Probed by Raman Spectroscopy. The Journal of Physical Chemistry B 2016, 120 (42), 11035-11042.

31. Ray, P., Interactions of nitrogen and hydrogen with various 1D and 3D carbon materials probed via in-situ vibrational spectroscopy. Ph. D. Thesis 2016.

32. Petit, L.; Banwell, M. G.; Willis, A. C., The Total Synthesis of the Crinine Alkaloid Hamayne via a Pd[0]-Catalyzed Intramolecular Alder-Ene Reaction. Organic Letters 2011, 13 (21), 5800-5803.

33. Sreekumar*, R.; Padmakumar, R., Simple, Efficient and Convenient Synthesis of Pyrroles and Pyrazoles Using Zeolites. Synthetic Communications 1998, 28 (9), 1661-1665.

34. Rebstock, A.-S.; Mongin, F.; Trécourt, F.; Quéguiner, G., Synthesis and metallation of 2-(pyridyl)benzoic acids and ethyl 2-(pyridyl)benzoates: a new route to azafluorenones. Tetrahedron 2003, 59 (27), 4973-4977.

35. Alessi, M.; Larkin, A. L.; Ogilvie, K. A.; Green, L. A.; Lai, S.; Lopez, S.; Snieckus, V., Directed ortho Metalation-Boronation and Suzuki-Miyaura Cross Coupling of Pyridine Derivatives: A One-Pot Protocol to Substituted Azabiaryls. The Journal of Organic Chemistry 2007, 72 (5), 1588-1594.

36. Allais, C.; Liéby-Muller, F.; Rodriguez, J.; Constantieux, T., Metal-Free MichaelAddition-Initiated Three-Component Reaction for the Regioselective Synthesis of Highly Functionalized Pyridines: Scope, Mechanistic Investigations and Applications. European Journal of Organic Chemistry 2013, 2013 (19), 4131-4145.

37. Ray, J. K., Stereoselective Synthesis of Bioactive Compounds (Track) Use of "halo vinyl aldehydes" in organic synthesis and chemo selective functional group transformations in gamma lactam derivatives.

38. Roy, B. C.; Gupta, M. D.; Bhoumik, L.; Ray, J. K., Spectroscopic investigation of water-soluble polyaniline copolymers. Synthetic Metals 2002, 130 (1), 27-33.

39. Mal, S. K.; Ray, D.; Ray, J. K., Palladium-catalyzed tandem oxidative cyclization of 1-bromohexa-1,5-dien-3-ols: easy access to cyclopentenones. Tetrahedron Letters 2004, 45 (2), 277-279.

40. Ray, D.; Mal, S. K.; Ray, J. K., Palladium-Catalyzed Novel Cycloisomerization: An Unprecedented Domino Oxidative Cyclization towards Substituted Carbocycles. Synlett 2005, 2005 (14), 2135-2140.

41. Ray, D.; Ray, J. K., Novel Synthetic Approach Toward ( \pm )- $\beta$-Cuparenone via Palladium-Catalyzed Tandem Heck Cyclization of 1-Bromo-5-methyl-1-aryl-hexa-1, 5-dien3-ol Derivatives. Organic letters 2007, 9 (2), 191-194. 
42. Brahma, S.; Ray, J. K., Halovinyl aldehydes: useful tools in organic synthesis. Tetrahedron 2008, 64 (13), 2883-2896.

43. Jana, R.; Chatterjee, I.; Samanta, S.; Ray, J. K., Novel and rapid palladium-assisted 6pi electrocyclic reaction affording 9,10-dihydrophenanthrene and its analogues. Org Lett 2008, 10 (21), 4795-7.

44. Jana, R.; Samanta, S.; Ray, J. K., Substrate dependent intramolecular palladiumcatalysed cyclisation and subsequent $\beta-\mathrm{H}$ elimination or $\mathrm{C}-\mathrm{H}$ activation: a general method for the synthesis of fused pyran rings. Tetrahedron Letters 2008, 49 (5), 851-854.

45. Samanta, S.; Mohapatra, H.; Jana, R.; Ray, J. K., Pd (0) catalyzed intramolecular Heck reaction: a versatile route for the synthesis of 2-aryl substituted 5-, 6-, and 7-membered O-containing heterocycles. Tetrahedron Letters 2008, 49 (50), 7153-7156.

46. Paul, S.; Samanta, S.; Ray, J. K., Palladium-catalyzed one-pot Suzuki coupling followed by arylpalladium addition to aldehyde: A convenient route to fluoren-9-one derivatives. Tetrahedron Letters 2010, 51 (42), 5604-5608.

47. Nandi, S.; Singha, R.; Samanta, S.; Ray, J. K., Synthesis of pentalongin and C (1)and C (3)-substituted pentalongin using intramolecular Heck reaction. Tetrahedron Letters 2012, 53 (21), 2659-2661.

48. Ray, D.; Nasima, Y.; Sajal, M. K.; Ray, P.; Urinda, S.; Anoop, A.; Ray, J. K., Palladium-Catalyzed Intramolecular Oxidative Heck Cyclization and Its Application toward a Synthesis of $( \pm)$ - $\beta$-Cuparenone Derivatives Supported by Computational Studies. Synthesis 2013, 45 (09), 1261-1269.

49. Singha, R.; Roy, S.; Nandi, S.; Ray, P.; Ray, J. K., Palladium-catalyzed one-pot Suzuki-Miyaura cross coupling followed by oxidative lactonization: a novel and efficient route for the one-pot synthesis of benzo[c]chromene-6-ones. Tetrahedron Letters 2013, 54 (7), 657-660.

50. Nandi, S.; Singha, R.; Ray, J. K., Palladium catalyzed intramolecular cascade type cyclizations: Interesting Approach towards naphthoquinone derivatives having an $\mathrm{O}$ containing heterocyclic skeleton. Tetrahedron 2015, 71 (4), 669-675.

51. Brahma, S.; Ray, P.; Singha, R.; Ray, J. K., Visible Colourimetric and Ratiometric Fluorescent Chemosensors for $\mathrm{Cu}$ (II) and Ni (II) Ions. Asian Journal of Chemistry 2016, 28 (5), 1035.

52. Chaudhuri, S.; Maity, S.; Roy, M.; Ray, P.; Ray, J. K., A Vinyl Radical Cyclization Route to Hydroxycyclohexene Fused Carbocycles. Asian Journal of Chemistry 2016, 28 (1).

53. Ghosh, M.; Ray, J. K., Ten years advancement in the synthetic applications of 2bromo-cyclohexenecarbaldehydes and 2-bromobenzaldehydes and derived substrates under palladium-catalyzed cross-coupling conditions. Tetrahedron 2017, 73 (27-28), 3731-3799.

54. Ray, J. K.; Paul, S.; Ray, P.; Singha, R.; Rao, D. Y.; Nandi, S.; Anoop, A., Pdcatalyzed intramolecular sequential Heck cyclization and oxidation reactions: a facile pathway for the synthesis of substituted cycloheptenone evaluated using computational studies. New Journal of Chemistry 2017, 41 (1), 278-284.

55. Ray, J. K.; Singha, R.; Ray, D.; Ray, P.; Rao, D. Y.; Anoop, A., Palladiumcatalyzed expedient Heck annulations in 1-bromo-1,5-dien-3-ols: Exceptional formation of fused bicycles. Tetrahedron Letters 2019, 60 (13), 931-935.

56. Sarkar, P.; Ahmed, A.; Ray, J. K., Suzuki cross coupling followed by cross dehydrogenative coupling: An efficient one pot synthesis of Phenanthrenequinones and analogues. Tetrahedron Letters 2020, 61 (13), 151701.

57. Jayanta, R.; Leena, B., Spectroscopic Investigation of Polyaniline Co Poly Meta Amino Benzene Sulfonic Acid. 2021.

58. Ray, J.; Bhowmik, L., Preparation and Evaluation of Novel Bamboo-Polymer Composites. 2021. 
59. Ray, J.; Bhowmik, L., Sol Gel Technique to Prepare Composite Material of GlassDye-Polymers. 2021. 